\begin{tabular}{|c|c|c|}
\hline & Int.J.Curr.Microbiol.App.Sci (2021) 10(08): 107-109 & \\
\hline & $\begin{array}{l}\text { International Journal of Current Microbiology and Applied Sciences } \\
\text { ISSN: 2319-7706 Volume } 10 \text { Number } 08 \text { (2021) } \\
\text { Journal homepage: http://www.ijcmas.com }\end{array}$ & $\$ 20$ \\
\hline $\begin{array}{l}\text { EXCELLENT } \\
\text { PUBLISHERS }\end{array}$ & & muwwijicmas com \\
\hline
\end{tabular}

Review Article

https://doi.org/10.20546/ijcmas.2021.1008.014

\title{
Organic Foliar Nutrient Management in Major Cereals and Millets: An Overview
}

\author{
A. K. Behera* \\ Department of Agronomy, College of Agriculture, Dharwad University of Agricultural \\ Sciences, Dharwad-580005, Karnataka, India \\ *Corresponding author
}

Keywords

Vermiwash,

Jeevamrutha, Cow urine, Panchagavya, Organic farming, foliar application

Article Info

Accepted:

12 July 2021

Available Online:

10 August 2021

\section{A B S T R A C T}

Cereal crops are high $\mathrm{N}$ requirement crops as compare to other crops. They are heavy feeder of all the essential nutrients such as N, P, and K. They are exhaustive in nature. Due to erratic use of chemical fertilizers; the soil fertility has been decreasing day by day resulting low productivity. It is due to many unavoidable reasons associated with crop production. The similar problems are seen in organic farming when inputs were soil applied. It may be due to various losses or inappropriate application of organic inputs to the soil or insufficiency to meet the crop demand. To equalize the yield potential for cereal and millet crops the foliar nutrient management through organic formulations suitably fulfilling the nutrient requirement. The organic formulations such as vermiwash, jeevamrutha, cow urine, and panchagavya are most frequently used by the researchers and farmers so reviewing on this aspect has more important.

\section{Introduction}

India is the largest producer of millets, second largest producer of wheat, rice and occupied sixth rank in global maize production. During 2019-20, food grain production estimated to reach a record 295.67 million tonnes (Anonymous, 2020). In 2020-21, Government of India is targeting food grain production of $298 \mathrm{mt}$. India is self-sufficient in food because of green revolution, but due to ill effects of green revolution, India had to follow non- synthetic agriculture through natural farming and organic farming etc., and then the trend begins with the various names with some modified concept of ancient farming systems.

The cereal crops shows deficiency symptoms in spite of application of organic manures through soil due to the tying, slow acting, less efficient and leaching loss of nutrients in soil. There is a scope created for foliar feeding of nutrients enormously. Foliar application helps in faster uptake of applied nutrients, no ties up 
by the soil and no leaching loss. So it is more efficient than the soil application.

\section{Research studies}

To justify the claim some research studies has been attached in the following. Those are clearly showing a picture why we should use organic formulations over chemical fertilizers.

\section{Effect of organic formulations on growth and yield of cereals and millets}

Sharada and Sujathamma, (2018) ${ }^{(9)}$ presented that use of Vermicompost + Panchagavya @ 3 \%+Jeevamrutha@5\% in combination with $50 \%$ NPK resulted higher grain and straw yield in DRR Dhan 39 variety of rice and in case of RP BIO 226, organic treatment such as Vermicompost + Panchagavya @ $3 \%$ + Jeevamrutha @ 5\% gave significantly higher grain yield. Raman and Krishnamoorthy, $(2019)^{(7)}$ showed that the application of Vermiwash @6\% two times at active tillering and $50 \%$ flowering time has resulted significantly higher yield in paddy which is on par with panchagavya @ $6 \%$. Rajan and Murugesan, (2012) ${ }^{(5)}$ showed that spray of 100 $\%$ vermiwash significantly increased the germination \%, shoot and root length and vigor index. It is may be due to presence of growth promoters like and good nutrients source. Kaur and Saini, (2019) ${ }^{(3)}$ reveals that the application of Jeevamrutha @ 20\% in two weeks interval resulted higher biological yield, grain and straw yield, harvest index in wheat which is on par with Jeevamrutha @ $10 \%$ in 2 weeks interval. Sadhukhan et al., $(2018)^{(8)}$ showed that application of $100 \%$ cow urine resulted significantly higher grain and straw yield which is on par with $75 \%$ cow urine in wheat crop. Ramesh et al., (2018) ${ }^{(6)}$ showed that foliar spray of Jeevamrutha @ $5 \%$ at 20, 40 and 60 DAS gave significantly higher growth; yield attributes and yield in maize. It may be due to presence of growth promoting substances such as IAA, GA, Cytokinin, Kinetin, essential plant nutrients, effective micro organisms that directly influence LAI, increase photosynthesis and assimilate partitioning from source to sink. Vimalendran and Wahab, $(2013)^{(10)}$ revealed that the treatment $100 \% \mathrm{RDF}+4$ sprays of panchagavya@3\% at 15, 25, 35 and 45 DAS gave the significantly higher growth, yield attributes and yield in baby corn. Ananda et al., $(2017)^{(1)}$ showed that the application of Panchagavya through foliar spray @ $3 \%$ along with enriched biodigester liquid manure @ $25 \mathrm{~kg} \mathrm{~N}$ equivalent/ha increased the growth and yield parameters in finger millet which is on par with Vermiwash @ 3\% along with enriched biodigester liquid manure @ 25 kg N equivalent/ha. Kumaran and Parasuraman, $(2019)^{(4)}$ showed that application of enriched $\mathrm{FYM}+\mathrm{RDF}+3 \%$ panchagavya one spray at 20 DAS has improved the grain yield which is on par with application of enriched FYM + RDF in foxtail millet.

\section{Effect of organic foliar application on economics of cereals and millets}

Kaur and Saini, (2019) showed that application of Jeevamrutha @ $10 \%$ in 3 weeks interval resulted higher B:C ratio in wheat which is on par with Jeevamrutha @ 10 $\% 2$ weeks interval. Vimalendran and Wahab, (2013) showed that $100 \%$ RDF +4 sprays of $3 \%$ panchagavya at $15,25,35,45$ DAS gave the higher $\mathrm{B}: \mathrm{C}$ ration in baby corn.

Results of these investigations are clear pointer to the farming community that the organic foliar nutrition were recommended in view of its cost effectiveness and ecological safety.

Jeevamrutha@10\% or $20 \%$, panchagavya @3\%, vermiwash@6\% and cow urine @ $100 \%$ are better to get higher productivity and economical return in cereals and millets. 


\section{References}

Ananda, M. R., Sharanappa and Murthy, K. N. K., 2017, Response of finger millet under organic nutrient management in groundnut (Arachis hypogaea L.) finger millet (Eleusine coracana L.) cropping system, Int. J. Pure App. Biosci. 5(5): 200-206.

Devakumar, N., Rao, G. G. E. and Shuba, S., 2011, Evaluation of locally available media for the growth and development of nitrogen fixing micro-organisms. Proceedings of the 3rd scientific conference of ISOFAR Organic are life knowledge for tomorrow, held on 28th September-01 october 2011, Korea.PP 504-509.

Kaur, P. and Saini, J. P., 2019, Standardization of the doses and time of application of "Jeevamrit" in wheat under natural farming system. M.Sc. (Agri.) Thesis, Csk Himachal Pradesh Agricultural University, Palampur; 89 p.

Kumaran, G. and Parasuraman, P., 2019, Effect of enriched FYM and Panchagavya spray on foxtail millet (Setaria italica) under rainfed conditions. Int. J. of Che. Studies, 7(2): 2121-2123.

Rajan, M. R. and Muruhesan, P., 2012,
Influence of Vermiwash on Germination and Growth of Cow Pea (Vigna Ungiculata) and Rice (Oryza Sativa). IOSR J. of Pha. Sci., p-ISSN: 2319-4219, Vol. 2, Issue 6, Nov-Dec. 2012, PP. 31-34.

Ramesh, S., Sudhakar, P. and Elankavi, S., 2015, Effect of liquid organic supplements on growth and yield of maize (Zea mays L.), Int. J. of Curr. Res., 07, (11), 23119-23122.

Raman, R. and Krishnamoorthy, R., 2019, Impact of organic foliar nutrition and its efficacy on sustainable production of Rice. Acta Sci. Agri., 3(10): 61-63.

Sadhukhan, R., Bohra, J. S. and Sourav, C., 2018, Effect of fertility levels and cow urine foliar spray on growth and yield of wheat. Int. J. of Curr. Microbio. App. Sci., 7(03): 907-912.

Sharada, P. and Sujathamma, P., 2018, Effect of Organic and Inorganic Fertilizers on the Quantitative and Qualitative Parameters of Rice (Oriza sativa L.). Curr. Agri. Res. J., ISSN: 2347-4688, Vol. 6, No.(2) 2018, pg. 166-174.

Vimalendran, L. and Wahab, K., 2013, Effect of foliar spray of panchagavya on yield attributes, yield and economics of baby corn, J. of Agro., 12(2): 109-112.

\section{How to cite this article:}

Behera, A. K. 2021. Organic Foliar Nutrient Management in Major Cereals and Millets: An Overview. Int.J.Curr.Microbiol.App.Sci. 10(08): 107-109. doi: https://doi.org/10.20546/ijcmas.2021.1008.014 